\title{
Pertimbangan Kaidah Struktur pada Transformasi Bentuk Arsitektur
}

\author{
Bambang Subekti ${ }^{1}$ \\ ${ }^{1}$ Program Studi Arsitektur, Fakultas Arsitektur dan Desain \\ Itenas, Institut Teknologi Nasional Bandung \\ Email: ambang@itenas.ac.id
}

\begin{abstract}
ABSTRAK
Kaidah struktur seringkali merupakan penghambat proses kreatif bagi arsitek dalam merancang bentuk bangunan. Karya-karya arsitektur hanya bermain pada kemasan saja, tanpa mempertimbangkan efisiensi struktur. Banyak sekali gedung tinggi walaupun fungsi dan tampilannya berbeda-beda namun diselesaikan dengan struktur yang sama, yaitu struktur inti dan rangka (core and frames), dan tidak jarang struktur disembunyikan ketidakteraturannya karena mengejar bentuk tertentu. Pendekatan struktur masih terkesan penuh dengan rumus dan angka, sehingga dianggap akan menghambat proses kreatif olahan bentuk dan ruang dalam proses transformasi bentuk. Akibat yang terjadi adalah tidak sedikit rancangan gedung yang memanipulasi bentuk luarnya dengan konstruksi tambahan, yang seringkali cenderung ornamental. Atau arsitek menghindar dari menampilkan strukturnya sebagai bagian dari estetika, walaupun dalam penyusunan konsep perancangan, analisis struktur merupakan proses yang harus dilalui untuk meyakinkan keterbangunan sebuah rancangan gedung. Kajian ini adalah suatu model pendekatan struktur pada kasus gedung tinggi pada tugas yang diberikan di Studio Mata kuliah Struktur Konstruksi III Program Studi Arsitektur Itenas. Diharapkan kajian ini dapat memberikan gambaran pendekatan kualitatif dalam konsep struktur yang dapat diterapkan dalam proses penyusunan konsep perancangan arsitektur, sehingga dapat menghasilkan bentuk struktur yang baik.
\end{abstract}

Kata kunci: gedung tinggi, kaidah struktur, transformasi bentuk

\begin{abstract}
The structural rules are often an obstacle to the creative process for architects in designing building forms. Architectural works only to create the enclosure of building, without considering the efficiency of the structure. There are so many tall buildings, although they have different functions and appearances, they are resolved with the same structure, namely the core and frame structure, and many structure are hidden by its irregularities due to pursuing a certain shape. The structural approach still seems full of formulas and numbers, so it is considered to hinder the creative on processing forms and spaces in the process of transforming forms. The result is that there are many building designs that manipulate the outer shape with additional construction, which often tends to be ornamental. Or architects avoid displaying their structure as part of aesthetics, even though in drafting a design concept, structural analysis is a process that must be passed to ensure the constructability of a building design. This study is a model of a structural approach in the case of tall buildings in the assignment given in the Studio Construction Structure III course of the Itenas Architecture Study Program. It is hoped that this study can provide an overview of a qualitative approach in structural concepts that can be applied in the process of drafting architectural design concepts, so as to produce good structural forms.
\end{abstract}

Keywords: structure rules, tall building, transformation of shape 


\section{PENDAHULUAN}

Dalam merancang sebuah lingkungan binaan, arsitek tidak bisa bekerja sendiri. Dibutuhkan proses berfikir secara menyeluruh yang merupakan integrasi antara kemampuan keteknikan dengan kemampuan arsitektur [1]. Perhatian Arsitek secara umum pada kebutuhan spasial dan kinerja teknisnya, sementara perhatian insinyur pada kekuatan, efisiensi, dan kenyamanan. Namun secara umum arsitek berperan menghubungkan keseluruhan subsistem sebagai desain lingkungan binaan secara lengkap.

Dalam proses penyusunan konsep perancangan, arsitek menata konsep integrasi keseluruhan subsistem dan belum melibatkan insinyur hingga rancangannya secara lengkap terkonsepkan, dan setelah itu para insinyur memodelkan perhitungannya, baik secara manual maupun dijital. Tahapan dalam konsep perancangan inilah arsitek mencoba mentransformasikan rancangannya dari tema-tema verbalnya ke dalam bentuk 3 dimensi. Konsep struktur, plambing, mekanikal, dll. menjadi bagian yang tidak terpisahkan dalam menjadikan produk 3 dimensinya menjadi utuh dan layak dikatakan sebagai karya arsitektur.

Konsep struktur dalam proses berarsitektur adalah untuk memilih konfigurasi struktur yang seperti apa yang akan diterapkannya. Dalam penerapan konfigurasi struktur ini, Charleson mengkategorikannya dalam dua sikap, yaitu form-followers, yaitu struktur digunakan untuk menopang bentuk/rancangan arsitektur, dan form-givers, yaitu struktur dipertimbangkan di awal untuk menentukan bentuk, sehingga jika strukturnya berubah, maka bentuk bangunanpun berubah. Dari studinya Suckle (Charleson, 2005), pertimbangan struktur yang dilakukan oleh 10 arsitek yang ditelitinya, walaupun tampil sangat kuat dalam desain arsitektur umumnya diselesaikan di akhir setelah proses yang panjang dalam mengolah bentuk, sehingga struktur tidak menghalangi, tetapi mengikuti maksud dari desain [2].

Ketika rancangan struktur itu dieksekusi oleh insinyur, maka kaidah-kaidah estetika tidak lagi menjadi bahan pertimbangan. Dan pada akhirnya banyak arsitek yang lebih memilih menutup/menyembunyikan tampilan struktur tersebut. Angus MacDonald (2001) mengkategorisasi hubungan desain struktur dan desain arsitektur tersebut sebagai structure accepted dan structure ignore [3]. Ketika hal ini terjadi pada rancangan arsitektur, rancangan menjadi terbatas pada memoles permukaan atau penampang bangunannya (dekoratif) [3].

Transformasi bentuk arsitektur terjadi pada saat arsitek menterjemahkan ide-ide verbalnya ke dalam bentuk fisik 3 dimensi. Pada saat itulah konsep-konsep sebagai pendekatan penerapan berbagai sistem ke dalam bentuk fisik bangunan disusun, termasuk di antaranya adalah konsep struktur.

\section{METODOLOGI}

\subsection{Metodologi}

Analisis terhadap struktur adalah bagian dalam proses rancangan arsitektur. Namun tidak selalu struktur dianalisis secara khusus untuk menjadi bagian dalam estetika arsitektur. Bentuk struktur sebagai pembentuk arsitektur (form giver) atau bentuk struktur hanya mengikuti arsitekturnya saja (form follower). 


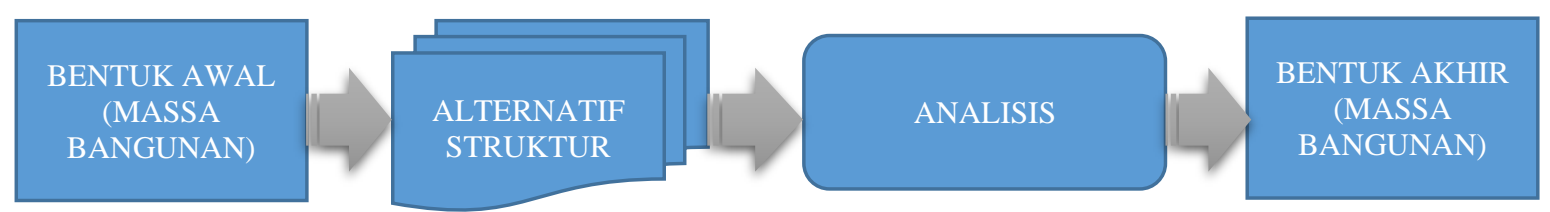

Gambar 1. Diagram pemikiran penelitian

Penelitian ini menggunakan metodologi analisis kualitatif berdasarkan hasil simulasi aplikasi Dr Frame-2D 1.0, sebagai validasi terhadap model rancangan struktur. Variabel analisis yang mempengaruhi hasil simulasi antara lain: bentuk dan konfigurasi stuktur, jumlah komponen struktur, jenis join dan besaran gaya. Hasil simulasi berupa perbandingan antara visualisasi desain konfigurasi struktur terhadap visualisasi deformasi struktur yang terjadi, untuk selanjutnya ditetapkan alternatif desain struktur yang sesuai dengan karakteristik beban, kaidah-kaidah struktur, dan logika strukturnya.

\subsection{Proses Transformasi Bentuk}

Banyak bentuk bangunan terjadi dari proses transformasi bentuk dasar. Variasi bentuk terjadi karena manipulasi dari ukuran dari bentuk tersebut ataupun penambahan/pengurangan (adisi/substraksi) dengan menggabungkannya dengan bentuk yang lain.

\subsubsection{Bentuk Dasar/Basic Shape}

Menurut Ching (2015), pengolahan bentuk berawal dari bentuk dasar (lingkaran dan persegi), Gambar 2 , yang digabung menjadi bentuk yang volumetric atau merupakan rangkaian dari garis-garis yang membentuk ruang [4], Gambar 3.

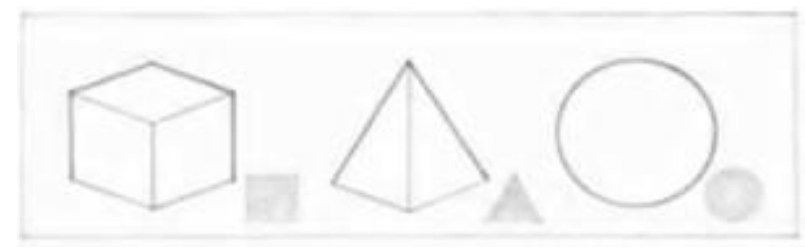

Gambar 2. Gambar 1 Bentuk Dasar (shape) Sumber: Francis DK Ching, 2015
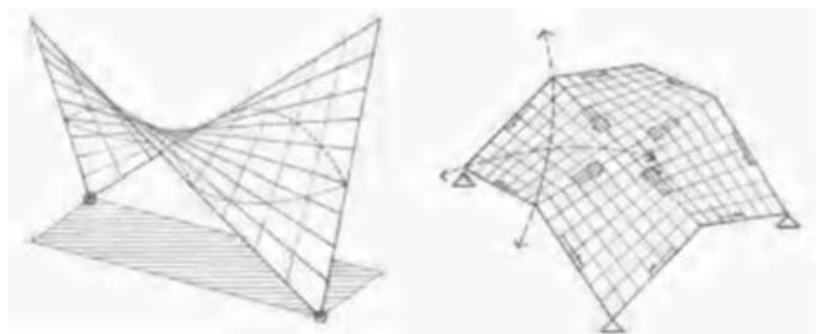

Gambar 3. Garis Pembentuk Bentuk Dasar (shape) Sumber: Francis DK Ching, 2015

Schueler mengelompokkannya dalam 3 lingkup pendekatan/alasan perwujudan bentuknya, yaitu material space (bangunan sebagai struktur, bangunan sebagai proses konstruksi, bangunan sebagai susunan komponen), formal space (bangunan adalah suatu idea, bangunan sebagai susunan/rakitan ruang), atau functional space (bangunan sebagai wadah aktivitas, bangunan sebagai pelindung terhadap iklim) [5].

Pendekatan material space dilakukan ketika rancangan diawali dengan susunan komponen struktur seperti halnya dilakukan pada masa lalu, yaitu bentuk bangunan muncul karena konsekuensi dari tumpukan elemen-elemen bangunan, misalnya batu yang ditumpuk pada bangunan di masa yunani, rumah iiglo pada masyarakat penghuni kutub utara. Atau ide industrialisasi komponen, seperti desain rumah sakit di Wuhan yang berkapasitas 1000 bed dan dibangun dalam waktu 10 hari untuk mengatasi korban virus C-19. Pendekatan formal space lebih menekankan pada dasar filosofis perwujudan 
bentuk massa dan ruang. Pendekatan ini bisa sifatnya terraga seperti pendekatan geometris, maupun tidak terraga seperti makna atau tata nilai. Pendekatan functional space dilakukan ketika tuntutan fungsional menjadi sesuatu yang dominan di dalam rancangan, seperti pendekatan bioklimatik atau alur aktivitas yang baku, seperti alur produksi pada sebuah pabrik. Proses eksplorasi bentuk menggunakan software sketchup akan sangat membantu dalam menemukan bentuk-bentuk massa bangunan, tetapi di sisi lain arsitek harus dapat memberikan solusi atas konsekuensi yang terjadi.

\subsubsection{Pemilihan Sistem Struktur}

Ketika gubahan massa sudah terbentuk, sistem struktur mulai diintegrasikan ke dalam bentuk massa. Bentuk massa yang solid diubah menjadi rangkaian komponen yang menunjukkan susunan komponen struktur yang logis dan efisien. Pada tahap ini pola-pola moduler digunakan sebagai alat bantu untuk menata ruang dalam. Pertimbangan yang sifatnya fungsional digunakan sebagai pendekatan dalam menentukan dimensi preferensi modulnya (grid struktur), misalnya fungsi bangunan, dimensi komponen/material, kendala konstruksi, dll. Kompleksitas permasalahan struktur akan terkait dengan tuntutan fungsinya, apakah akan berkembang pada arah vertikal menjadi bangunan tinggi atau pada arah horizontal menjadi bangunan berbentang lebar [6].

Akomodasi terhadap bangunan tinggi, di samping beban vertikal (gravitasi) yang semakin besar ketika bangunan semakin tinggi, juga beban horizontal, khususnya angin dan gempa menjadi hal yang perlu diselesaikan. Begitupun pada bangunan bentang lebar dengan reaksi yang berbeda. Dengan memahami pengaruh beban tersebut terhadap perilaku bangunan, arsitek dapat memahami kecenderungan deformasi yang terjadi terhadap struktur yang dipilihnya [7].

Dalam konteks massa bangunan, misalnya, bangunan harus terikat pada permukaan tanah, serta dapat dianalisis perilaku beban vertikal dan reaksinya hingga permukaan tanah, serta ketahanannya terhadap perilaku beban horizontal. Dan ketika massa bangunan sudah lebih didetailkan dalam bentuk rangkaian komponen, maka perilaku komponen sebagai reaksi dari beban yang mengalir dapat dianalisis kecenderungannya.

Pada pola struktur pendukung kolom, schueler mengklasifikasinya dalam 4 lokasi tipikal, yaitu: Multiple uniformly distributed, perimeter with intermediate, perimeter, dan concentrated, Gambar 4.
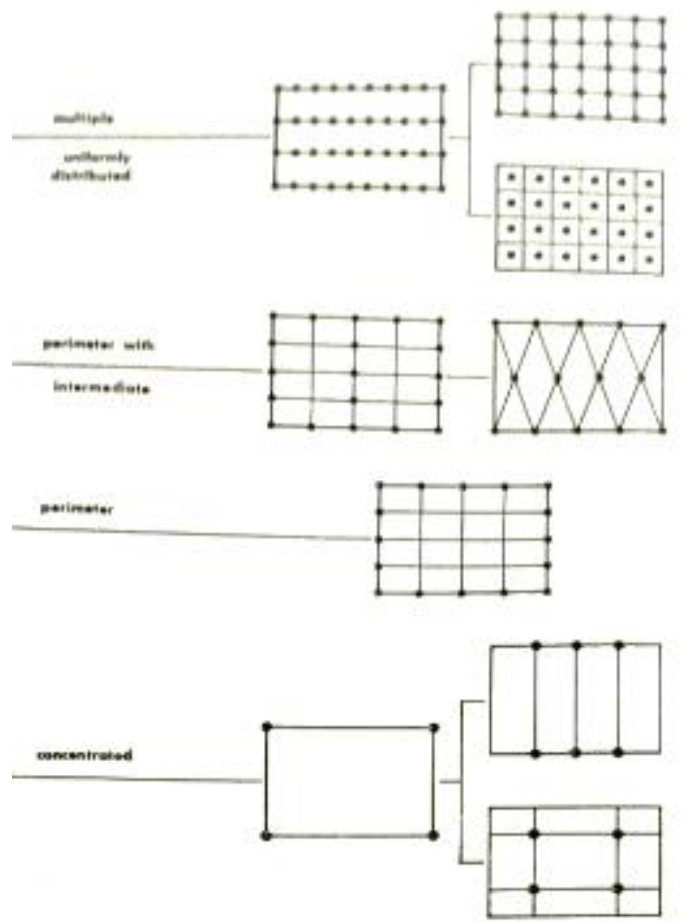

Gambar 4. Lokasi Tipikal Struktur Pendukung (kolom) Sumber: Schueler, 1990 
Sementara pola struktur pendukung berbentuk dinding dikelompokkan berdasarkan bentukan dinding dan ruang dengan tata letaknya, Gambar 5.

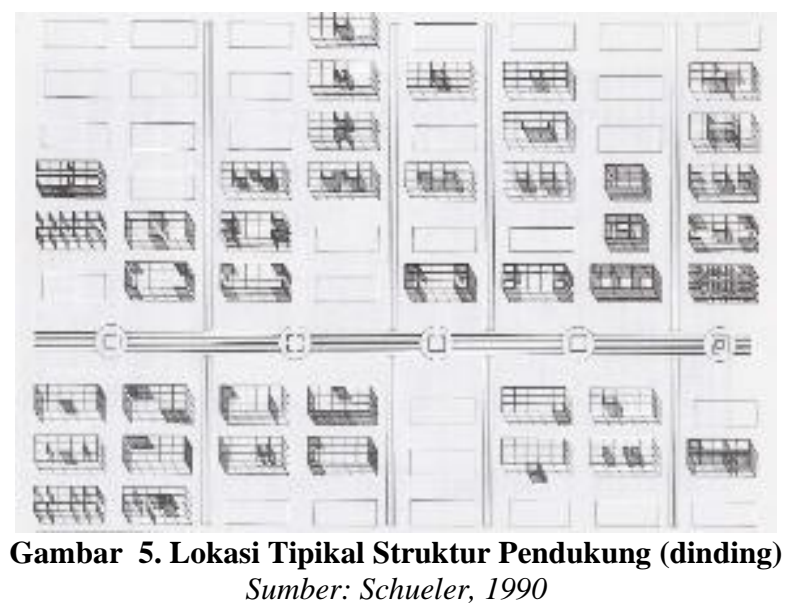

Pada rancangan gedung tinggi, elemen struktur pengkaku terhadap gaya horizontal menjadi utama, karena beban dominan tidak hanya di arah vertikal saja (beban dari pengaruh gravitasi), tetapi juga di arah horizontal. Sehingga penempatan sistem pengkaku struktur menjadi sangat penting. Ada 3 sistem pengkaku pada struktur yang bisa dijadikan sebagai pilihan dalam rancangan, yaitu: rigid frame connection, bracing (braced frame), dan shear wall. Prinsip kekakuan pada rigid frame connection adalah menahan deformasi pada sudut portal, bracing adalah menahan deformasi pada diagonal, dan shearwall mencegah deformasi pada bentuk (shape ) [8], Gambar 6.

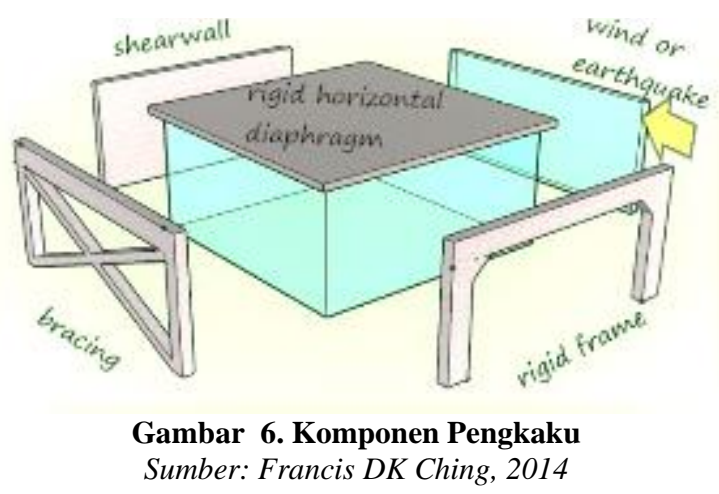

Dari 3 sistem pengkaku ini, pada gedung tinggi (vertical building), Engels (2009) mengklasifikasinya ke dalam 4 konfigurasi, yaitu: bay-type highrises, casing highrises, core highrises, dan bridge highrises. Klasifikasi ini didasarkan pada posisi dan bentuk struktur utamanya yang mengantisipasi beban vertikal dan horizontal. Bay-type highrises berdasarkan posisi portal/dinding kaku pada satu arah, casing highrises berdasarkan posisi pengkaku ada di kulit bangunan (surface), core highrises berdasarkan struktur kaku berbentuk tabung, dan bridge highrises berbentuk seperti jembatan yang membentang dari satu struktur pengkaku ke struktur pengkaku yang lain [9].

Untuk memaksimalkan integrasi antara bentuk arsitektur dan sistem struktur yang dipilihnya, seorang arsitek harus dapat menganalisis bentuk skematik yang dirancangnya terkait implikasi perilaku struktur, kekuatan dan efisiensi. Secara teknis arsitek akan dibantu oleh insinyur sipil, tetapi secara kualitatif implikasi perilaku struktur perlu dimodelkan oleh arsitek agar alternatif rancangan struktur dapat dimunculkan lebih kreatif. Hal ini tentu saja akan lebih mudah jika dibantu oleh simulasi menggunakan software. 
Dalam simulasi, arsitek dapat melihat pengaruh penambahan dan pengurangan komponen struktur tertentu terhadap deformasi struktur dan gaya-gaya dalam yang muncul (Tarik, tekan, geser, dll.). Sebagai contoh pada Gambar 7 dan Gambar 8, software Dr.Frame 1.0 [DrFWin4] versi demo digunakan untuk membantu transformasi bentuk yang dipertimbangkan oleh arsitek karena alasan fungsional ataupun yang lainnya [10].

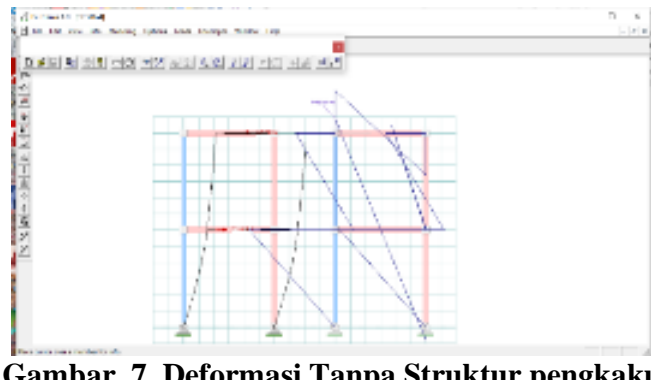

Gambar 7. Deformasi Tanpa Struktur pengkaku Sumber: hasil analisis, 2021

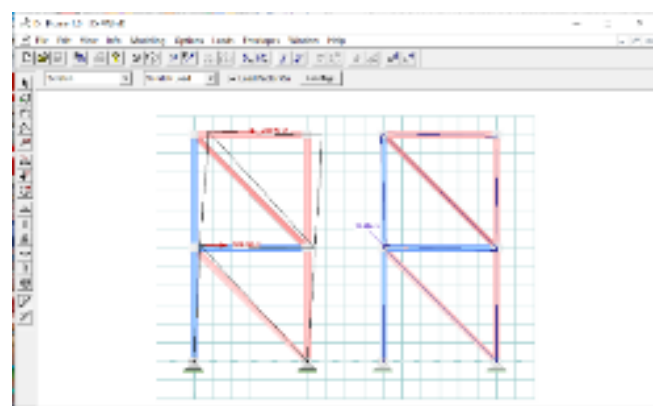

Gambar 8. Deformasi dengan Struktur pengkaku Sumber: hasil analisis, 2021

Walaupun masih terbatas pada dua dimensi, tetapi cukup membantu dalam mengantarkan pada pemahaman logika strukturnya. Pada display simulasi terdapat dua gambar, sebelah kiri adalah rancangan struktur dan simulasi pembebanan dan deformasi yang terjadi, sedangkan gambar sebelah kanan adalah skema dari diagram momen pada masing-masing komponen struktur. Namun sebelum simulasi tersebut dilakukan, arsitek perlu memahami karakteristik beban yang mempengaruhi bangunannya, agar dapat menentukan dan menandai secara tepat sistem gaya luar yang bekerja pada struktur yang dipilihnya, misalnya beban angin yang semakin ke atas semakin besar, beban hidup dan beban mati yang disimulasikan dalam bentuk beban merata, dll. Pemahaman arsitek terhadap karakteristik tumpuan akan memperkaya ide-idenya, khususnya berkenaan dengan bentuk elemen struktur yang lebih detail, misalnya dimensi balok tidak harus sama antara daerah tumpuan dengan daerah bentangan, karena dimensi ini sangat tergantung pada karakter gaya yang terjadi akibat pemilihan jenis tumpuan. Penggunaan jenis tumpuan akan berimplikasi pada karakter gaya geser dan momen pada elemen struktur. Heinrich Engels (2009), secara lengkap mengulas pengaruh tumpuan ini pada berbagai jenis struktur, baik pada bentang lebar, maupun pada bangunan tinggi.

Simulasi ini dilakukan pada gedung berlantai 10 dan memiliki 4 trave yang memiliki lebar masingmasing 7,2 meter. Jika struktur tidak menggunakan skema dinding geser, lendutan terjadi sangat besar, begitupun gaya dalam (momen) yang terjadi pada setiap komponennya (kolom dan balok) pun besar, Gambar 9. 


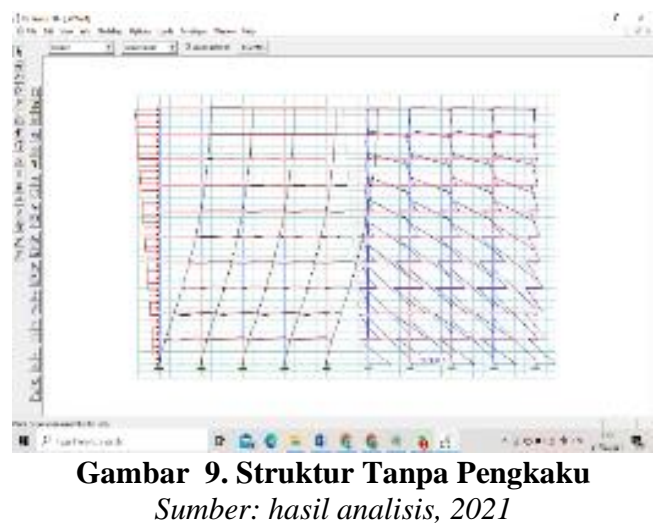

Ketika ditambahkan komponen dinding geser dalam bentuk bracing, secara visual dapat dilihat pengaruhnya sangat besar terhadap pengurangan lendutan dan momen, Gambar 10 dan Gambar 11.

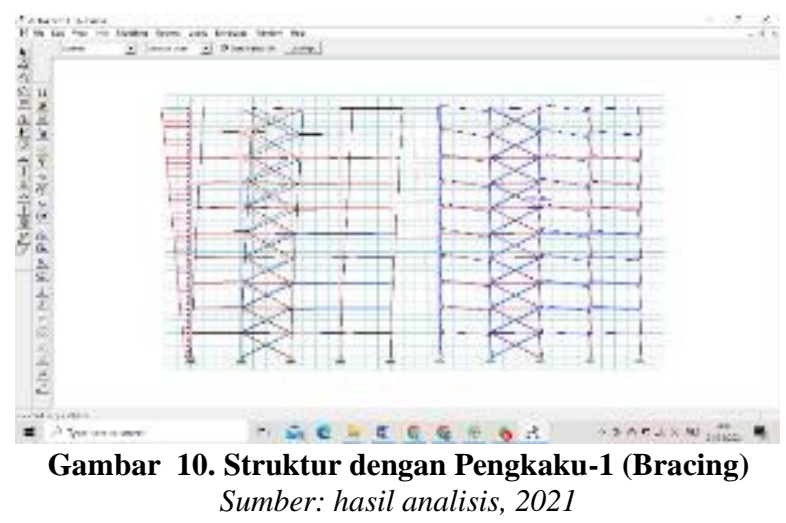

Demikian pula arsitek dapat mengeksplor kreativitasnya dengan membuat variasi penyaluran beban (menghilangkan/menambahkan komponen), Gambar 11.

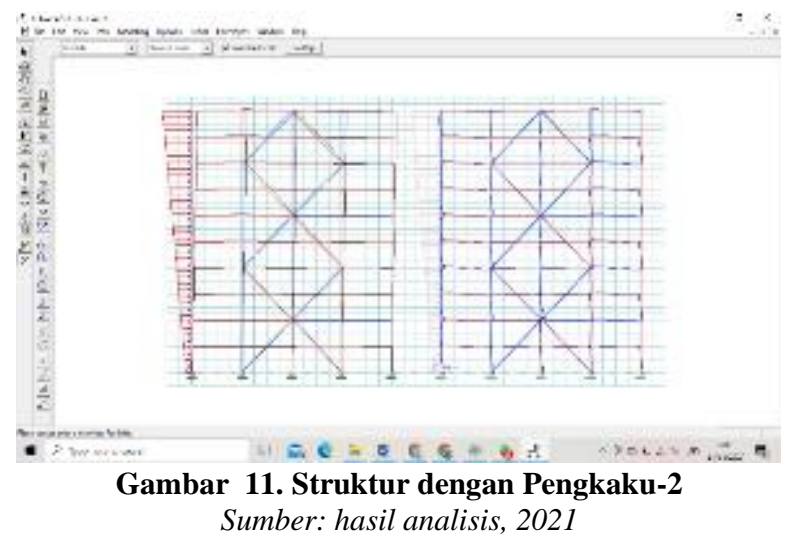

Lebih jauh, arsitek dapat mencoba variasi posisi perletakan struktur, jenis perletakan (jepit, sendi, roll), dan alternatif jenis material, misalnya batang tarik menggunakan baja dan batang tekan menggunakan beton/kayu, Gambar 12 . 


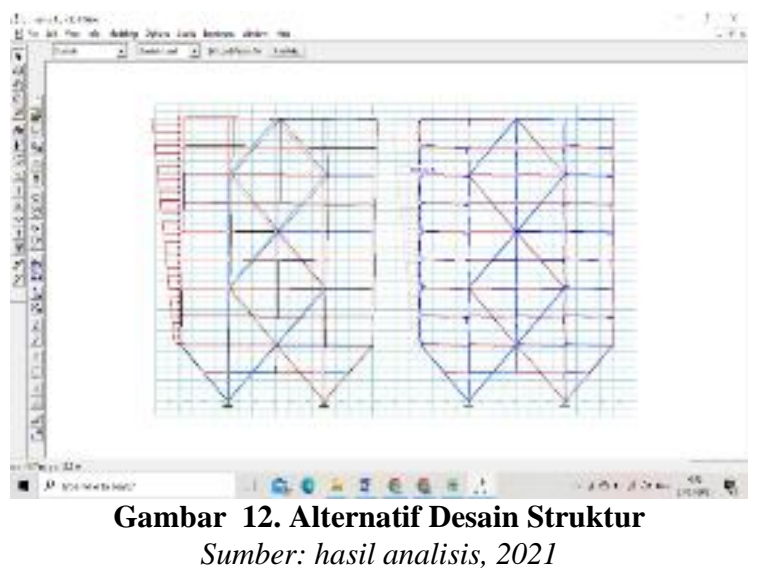

\section{HASIL DAN PEMBAHASAN}

Matakuliah Struktur dan Konstruksi III di program studi arsitektur Itenas berkenaan dengan studi struktur dan konstruksi bangunan tinggi (middle rise). Capaian matakuliahnya adalah diharapkan mahasiswa mampu menganalisis sistem struktur dan konstruksi pada desain bangunan berlantai 10 dan integrasinya dengan sistem keteknikan lainnya (air hujan, penghawaan/pengkondisian udara, penerangan/ pencahayaan, pengamanan kebakaran dan maintenance) [C4, P3, A3] [S9, KU2, KK3, P1, P4, P5, P11]. Matakuliah ini membahas tentang sistem struktur bangunan bertingkat menengah berlantai 10 meliputi sistem struktur bagian bawah (sub structure) dan sistem struktur atas (super structure) terhadap gaya- gaya akibat pembebanan, pemakaian bahan utama struktur bahan konstruksi pendukung, bahan penutup, modul struktur, desain core, prinsip utilitas dan metoda membangun sederhana.

Di studio mahasiswa diberikan beberapa model massa bangunan dengan variasi jumlah core dan bentuk massa, Gambar 13. Pada ranah struktur, pada tahap awal mahasiswa diminta untuk mengkaji bentuknya dan mentransformasikan bentuk massa tersebut ke dalam rangkaian komponen struktur, baik vertikal maupun horizontal. Mahasiswa diberikan pemahaman mengenai struktur gedung tinggi dengan pembebanan yang bekerja dan kaidah-kaidah struktur yang mengantisipasinya, serta variasi bentuk struktur yang mungkin bisa diterapkan.

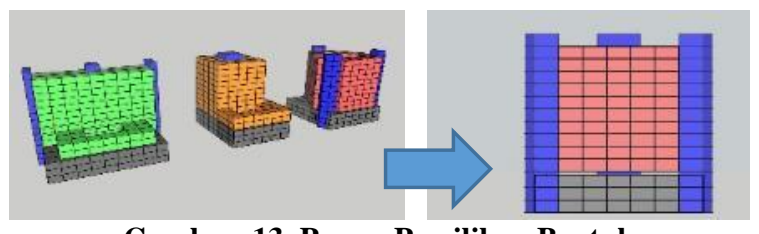

Gambar 13. Proses Pemilihan Bentuk Sumber: hasil analisis, 2021

Berdasarkan asumsi, fungsi ruang pada setiap lantainya, secara kreatif bisa dirancang suatu bentuk struktur yang unik. Misalnya rancangan gedung tinggi di pusat kota yang memiliki lahan yang sempit, BCR yang tinggi (misalnya 90\% atau 100\%), kebutuhan ruang kota sebagai fasilitas publik (ruang komunal), isu green building, dll. Dari batasan-batasan ini, ruang terbuka yang bebas kolom di lantai dasar daerah hijau pada bangunan (roof garden) menjadi jawaban rancangan arsitektur yang harus diselesaikan dalam konsep struktur, Gambar 14. Pada tahap ini tipe-tipe struktur dapat diterapkan secara kreatif. Penggunaan software simulasi struktur sangat membantu dalam bereksperimen, dengan memperhatikan deformasi yang terjadi, diagram momen, dan diagram geser. 


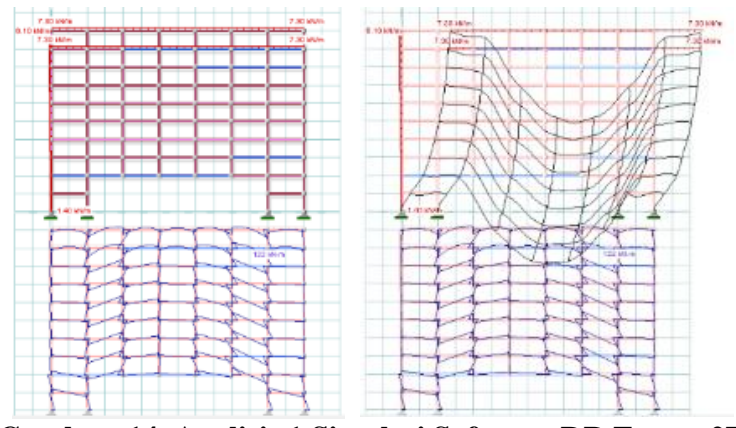

Gambar 14. Analisis 1 Simulasi Software DR Frame 2D Sumber: hasil analisis, 2021

Misalnya pada analisis 1 (Gambar 15), terlihat sekali, ketika kolom bagian bawah dihilangkan lendutan begitu besar (pada gambar dibuat skala lendutan yang besar supaya simulasi terlihat dengan jelas), begitupun pola diagram momen terutama pada kolom sangat besar.

Pola yang ditunjukkan, di samping sebagai alat kontrol, agar tidak terjadi simpangan/momen/gaya geser yang terlalu besar (ekstrim) dan rumit, juga bisa dijadikan bahan analisis terhadap bentuk komponen yang digunakan. Analisis 2 mensimulasikan penggunaan core di trave kiri dan kanan yang merupakan model bangunan yang diambil di tugas studio. Telihat simpangan pada kolom jauh berkurang, tetapi pada balok masih sangat besar.

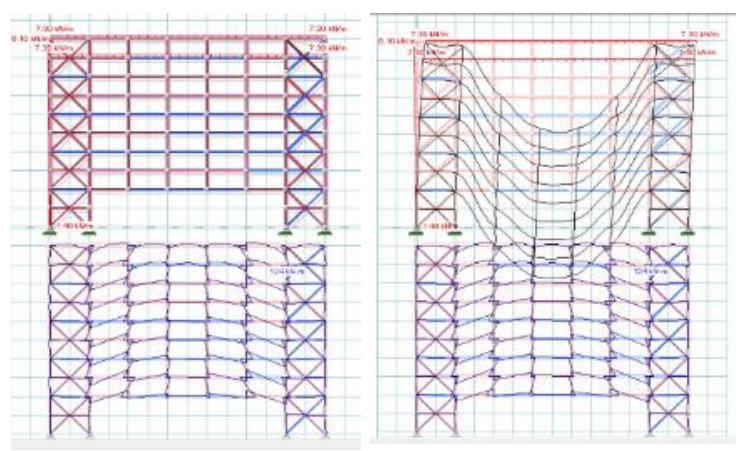

Gambar 15. Analisis 2 Software DR. Frame 2D Sumber: hasil analisis, 2021

Pada analisis ke 3 dan ke 4 dibuat simulasi penahanan beban tipe bridge highrises (klasifikasi dari Engels) Pada tahap ini ide-ide kreatif mahasiswa akan terintegrasi dengan pemahaman akan logika strukturnya. Pada tahap ini software DR Frame akan sangat membantu menganalisis pola yang dipilihnya, bahkan bisa membantu menganalisis perubahan struktur yang dilakukan.

Pada tahapan berikutnya pemahaman tentang karakter beban sangat penting untuk dikuasai. Secara umum beban pada gedung disederhanakan dalam dua tipe, yaitu beban vertikal dan beban horizontal. Sistem struktur dan kombinasinya dimodelkan sesuai dengan bentuk massa yang dipilih, lalu dianalisis dengan simulasi beban yang mempengaruhinya, Gambar 16. 


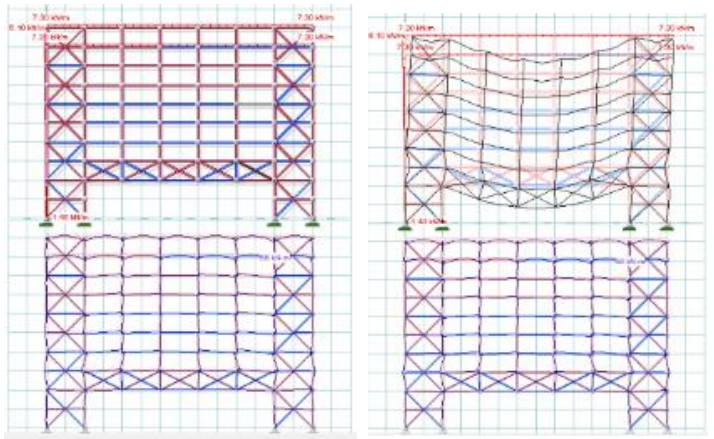

Gambar 16. Analisis 3 Software DR. Frame 2D Sumber: hasil analisis, 2021

Analisis dimensi kolom secara sederhana dapat dilakukan melalui analisis terhadap denah perletakan struktur untuk menentukan pola penyaluran beban akibat gravitasi (beban hidup dan beban mati), lalu dianalisis titik kolom mana yang paling berat menumpu beban, begitupun pada balok dengan menggunakan rule of thumb 1/12 bentangan untuk beton dan 1/20 bentangan untuk baja. Bentuk balok dan kolom dapat dianalisis dari karakteristik gaya dan momen yang terjadi pada elemen tersebut. Pada tahap ini informasi dari simulasi struktur yang diolah di software DR Frame sangat membantu. Misalnya dengan mencoba mengganti tumpuan balok yang asalnya jepit menjadi sendi, sehingga diharapkan momen pada kolom dapat berkurang, Gambar 17.

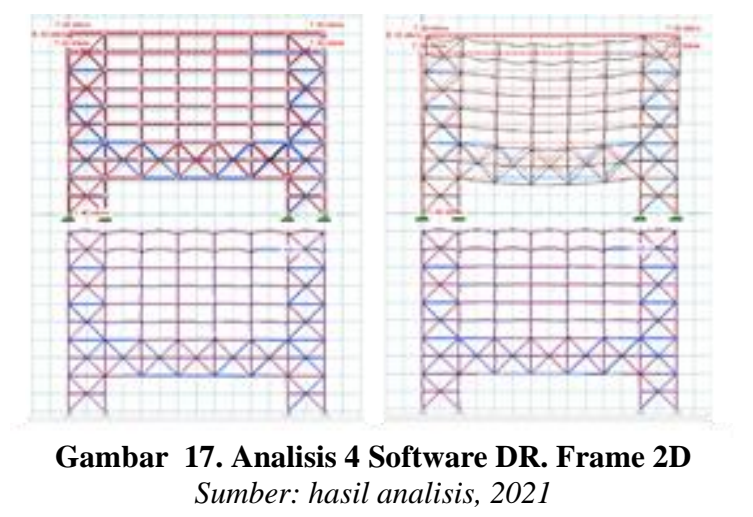

Hasil dari tahapan analisis ini, rancangan dapat diperhalus dengan pendekatan estetika, baik pada bentuk bangunan, tampilan fasad, atau ornamentasi pada strukturnya, apakah akan ditampilkan detailnya seperti karakter arsitekturnya Richard Rogers pada Lloyds Building atau ditutup menggunakan cladding seperti karakter arsitekturnya Norman Foster pada Hongkong Bank, atau ditutup cladding (curtain wall) seperti karakter arsitekturnya Hugh Stubin pada Citicorp Center

\section{SIMPULAN}

Rancangan gedung adalah integrasi berbagai sistem. Semakin baik integrasi berbagai sistem tersebut, maka rancangan akan semakin efektif dan konstruksi akan semakin efisien. Struktur pada gedung tinggi memiliki proporsi yang paling besar dalam pembiayaan konstruksi, sehingga dengan melakukan analisis di awal proses rancangan diharapkan dapat membuat rancangan lebih efisien. Untuk itulah arsitek diharapkan dapat lebih berperan dalam tahapan analisis ini. Kreativitas desain sangat ditentukan oleh penguasaan arsitek terhadap karakteristik beban, kaidah-kaidah struktur, dan logika strukturnya. Penggunaan software simulasi struktur sangat membantu dalam pembuktian logika struktur dan mempermudah dalam eksperimen model-model struktur. Pembelajaran struktur pada 
matakuliah Struktur dan Konstruksi III diharapkan memberikan stimulant awal bagi para calon arsitek dalam merancang dengan memperhatikan struktur sebagai potensi dalam desainnya.

\section{DAFTAR PUSTAKA}

[1] T. Y. Lin and S. D. Stotesbury, Structural Concepts and Systems for Architects and Engineers. John Wiley \& Sons, Inc., 1981.

[2] A. Charleson, Structure as Architecture: A Source Book for Architects and Structural Engineer. Architectural Press, 2005.

[3] A. J. MacDonald, Structure and Architecture, Second Edition, 2nd Ed. Architectural Press, 2001.

[4] F. D. K. Ching, Architecture, Form Space and Order, 4th Ed. Hoboken, New Jersey: John Wiley \& Sons, Inc., 2015.

[5] W. Schueler, Horizontal-Span Building Structure. New York: John Wiley \& Sons, Inc., 1983.

[6] D. L. Schodek, Structures, 7th Ed. New Jersey: Pearson Education, Inc., 2014.

[7] W. Schueler, Vertical Building Structure. Van Nostrand Reinhold, 1990.

[8] F. D. K. Ching, Building Structure Illustrated, Pattren, System, and Design, 2nd Ed. New Jersey: John Wiley \& Sons, Inc., 2014.

[9] H. Engels, Structure Systems. Stuttgart: Hatje Kantz, 2009.

[10] Dr Frame User Guides, Dr. Software, LLC, 1999. 